\title{
Monitoring harbour seal (Phoca vitulina) in the Danish Wadden Sea*
}

\author{
Svend Tougaard
}

Fishery and Maritime Museum; DK-6710 Esbjerg V., Denmark

\begin{abstract}
Monitoring of harbour seal (Phoca vitulina) has been carried out in the Danish part of the Wadden Sea during the past 8 years by the Fishery and Maritime Museum. In addition to this, field observations over three breeding seasons have been undertaken. The census shows a steady increase of approx. $14 \%$ per year. The distribution of the seals in the area can be split up into two different types of haulout localities, and a varied pattern of haulouts is observed during the year. The mass die-off in 1988 is discussed within the framework of the knowledge on the population, and it is recommended that more effort be put into monitoring and population studies of the harbour seal in the entire International Wadden Sea.
\end{abstract}

\section{INTRODUCTION}

Regular counting of harbour seals was not carried out in the Danish Wadden Sea until 1976, when hunting of the harbour seal was banned. Nevertheless, it is assumed that the seal population in the Danish part of the Wadden'Sea shows the same decrease as in other parts of the International Wadden Sea (Reijnders, 1978; Søndergaard et al., 1976; Drescher, 1979; Bøgebhergm 1876).

Since 1976, aerial census of the harbour seal has been carried out in the Danish Wadden Sea by The Danish Game Biology Station, and since 1981 it has been intensified by the Fishery and Maritime Museum.

During the breeding seasons 1983, 1984 and 1985, field observations were carried out in order to supplement the census with information on time-budget, behaviour and social structure of the harbour seal, to get a better estimation of the population size, and to find criteria for management of the population.

\section{METHODS}

\section{Aerial surveys}

The aerial surveys cover the entire Danish Wadden Sea and include a small part of the German territory, between the Danish-German border and the dam connecting the island of Sylt with the mainland. The surveys were carried out all year round, both at high and low tide, with special attention to the summer season when the peak haulout occurs.

\footnotetext{
- Presented at the VI International Wadden Sea Symposium (Biologische Anstalt Helgoland, Wattenmeerstation Sylt, D-2282 List, FRG, 1-4 November 1988) 


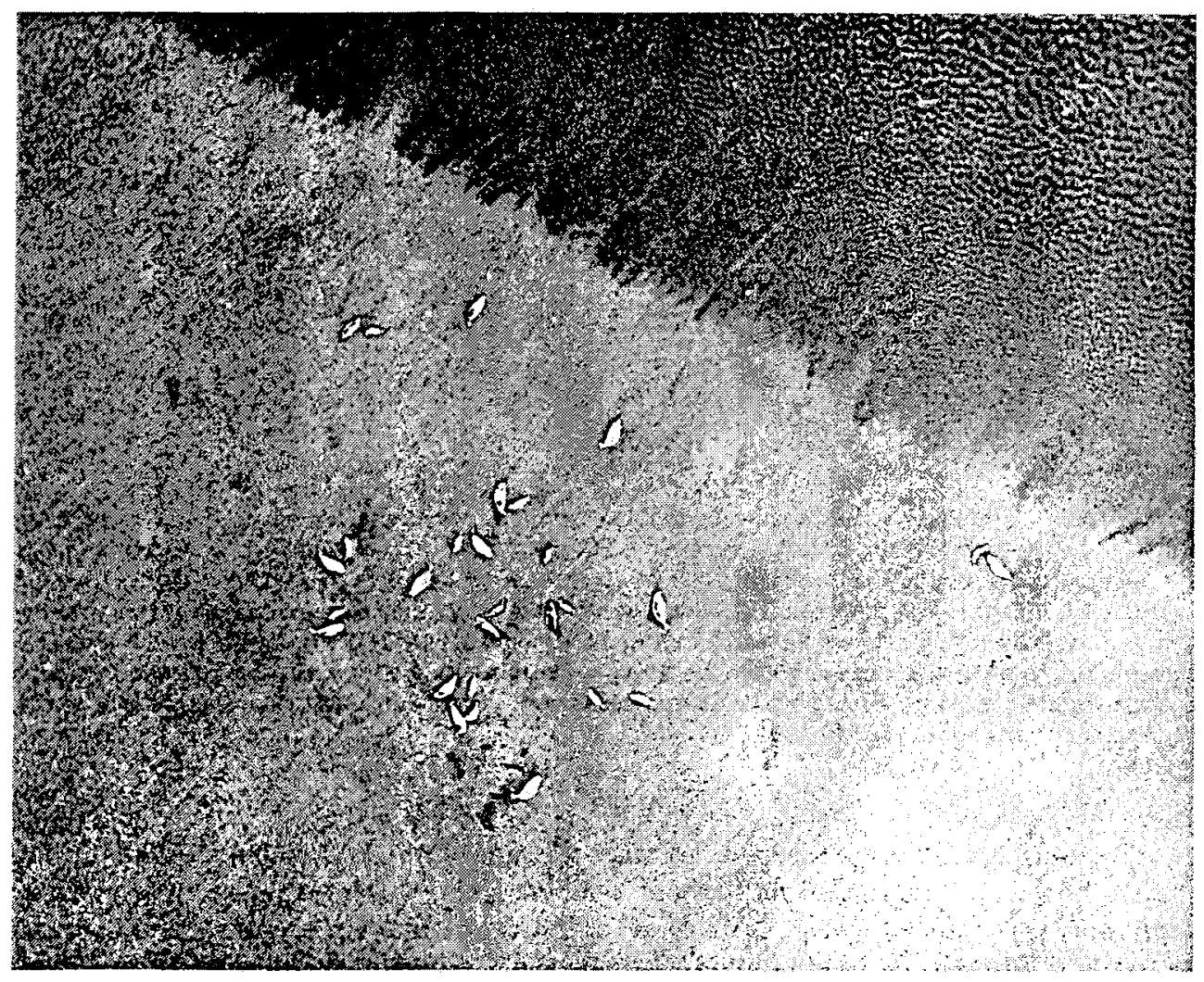

Fig. 1. Vertical photo of a seal bank (Paj Sand) with a clear pattern of an undisturbed haulout site. The seals spread deep on the bank. Note the high number of pups easily seen on the photo

In 1981 and 1982 monthly censuses were made, and in 1983 and 1984 weekly countings were made during the summer months. Due to a decline in funds, the countings have diminished since 1985. The aerial countings are documented by photographs, either vertical or horizontal, of each haulout site. Exact countings of animals can be made on the photos (Figs 1, 2).

The preferred method for photographic documentation is vertical photos, on which it is possible to separate each individual seal, and to distinguish between pups and other age groups during the breeding seasons. Furthermore, a fine view of the distribution pattern on each seal site is shown on this type of photo, and one has even the possibility of measuring the distance between the individual seals.

The vertical photos were taken with an automatic camera $(6 \times 6 \mathrm{~cm})$, mounted on the bottom of the aeroplane and controlled by a timer referring to the ground speed and the flight level. The flight level is approx. 1000 feet.

Horizontal photos were taken with a $23 \times 36 \mathrm{~mm}$ camera out of the window. This is a much easier and cheaper way of making the documentation, but one does not get the advantages of the vertical photos. On the other hand, one saves flight time, and one is able to fly at a lower altitude. This type of photo was mainly made in later years. 


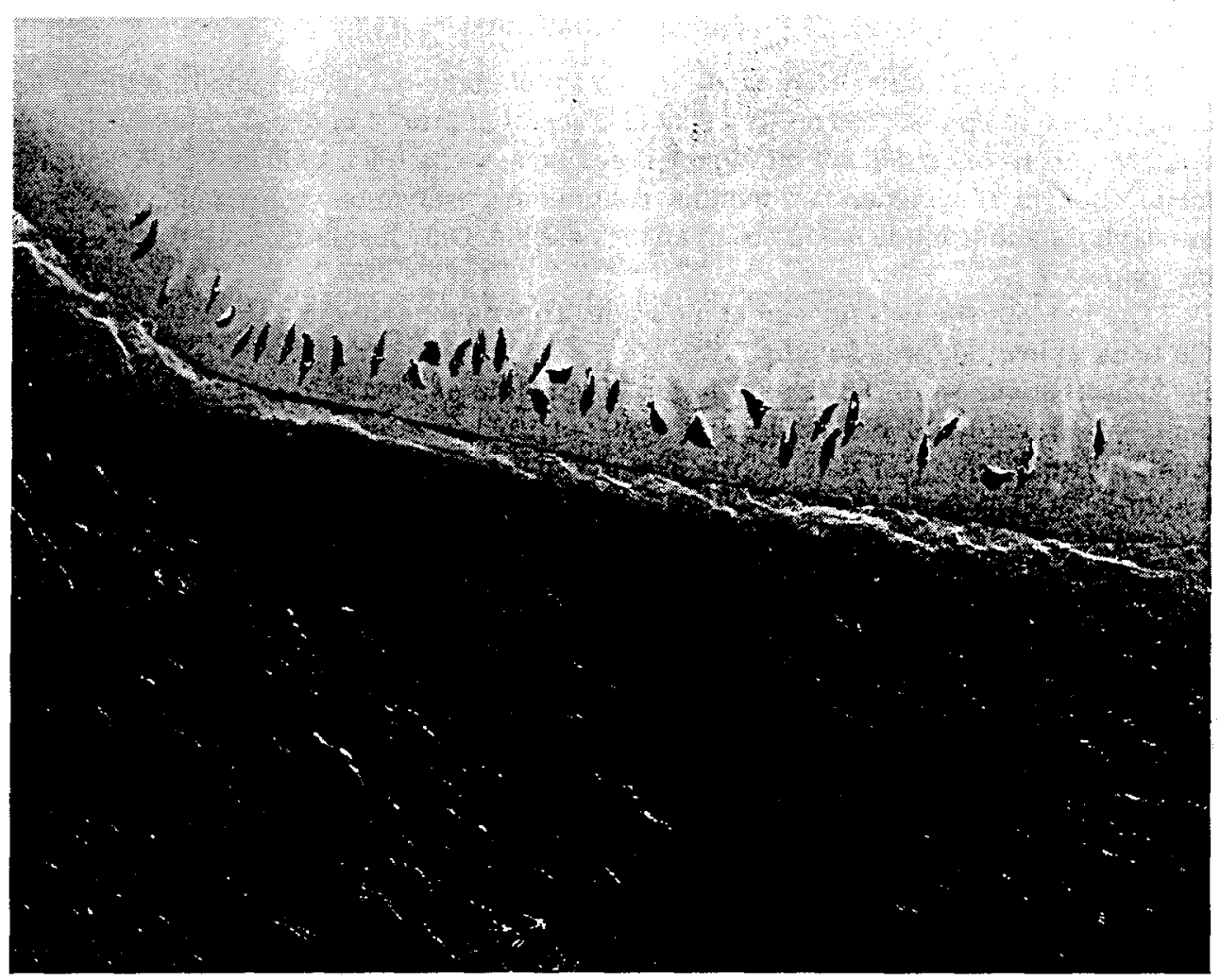

Fig. 2. Photo of a more often disturbed high sand bank where the seals are found in a row along the water edge

The results of the aerial surveys over the years do not show a constant increase but vary from year to year due to the difficulties in counting because of weather conditions and human influences (Table 1). Westerly winds shorten the period where seals are able to stay on land during a low tide, and boat traffic may interfere with the total number of seals. Furthermore, the most important seal area is located inside a military security zone and cannot be entered during daytime except when special permission is given.

Table 1. The number of seals counted in the Danish part of the Wadden Sea

\begin{tabular}{|llllllllllllll}
\hline Year & 1976 & 1977 & 1978 & 1979 & 1980 & 1981 & 1982 & 1983 & 1984 & 1985 & 1986 & 1987 \\
\hline $\begin{array}{l}\text { Number } \\
\text { of seals }\end{array}$ & 389 & 410 & 332 & 421 & 671 & 656 & 789 & 924 & 853 & 958 & 1261 & 1477 \\
\hline
\end{tabular}




\section{Field observations}

The field observations were made from a simple hide-out placed opposite the seals, at a distance of approx. $150 \mathrm{~m}$, with a tidal creek of approx. $4 \mathrm{~m}$ depth in between. The observations were carried out during the breeding seasons 1984, 1985 and 1986, with the major effort in 1985, when two months' continuous observations were made whenever the daylight and low tide made observations possible. Only results from 1985 are used in this paper.

The haulout site was flooded at high tide. The average time the seals could stay on the bank at low tide was 5 hours.

Observations were carried out during 76 low tide periods in 1985 . The seals on the bank were identified individually, and a total of 107 individual seals were identified by means of the pattern of the fur. An average of $95 \%$ of the seals on the bank were identified at each low tide.

This identification - where sex and age group were also known - allows the calculation of the time each individual seal spent on the bank during the available dry period.

On this basis, an estimate is made of the number of seals that do not stay on the banks during an aerial counting.

\section{RESULTS}

The census of the seals shows an average yearly increase of approx. $14 \%$ in the maximum number counted on land during low tide at the end of the summer (Fig. 3).

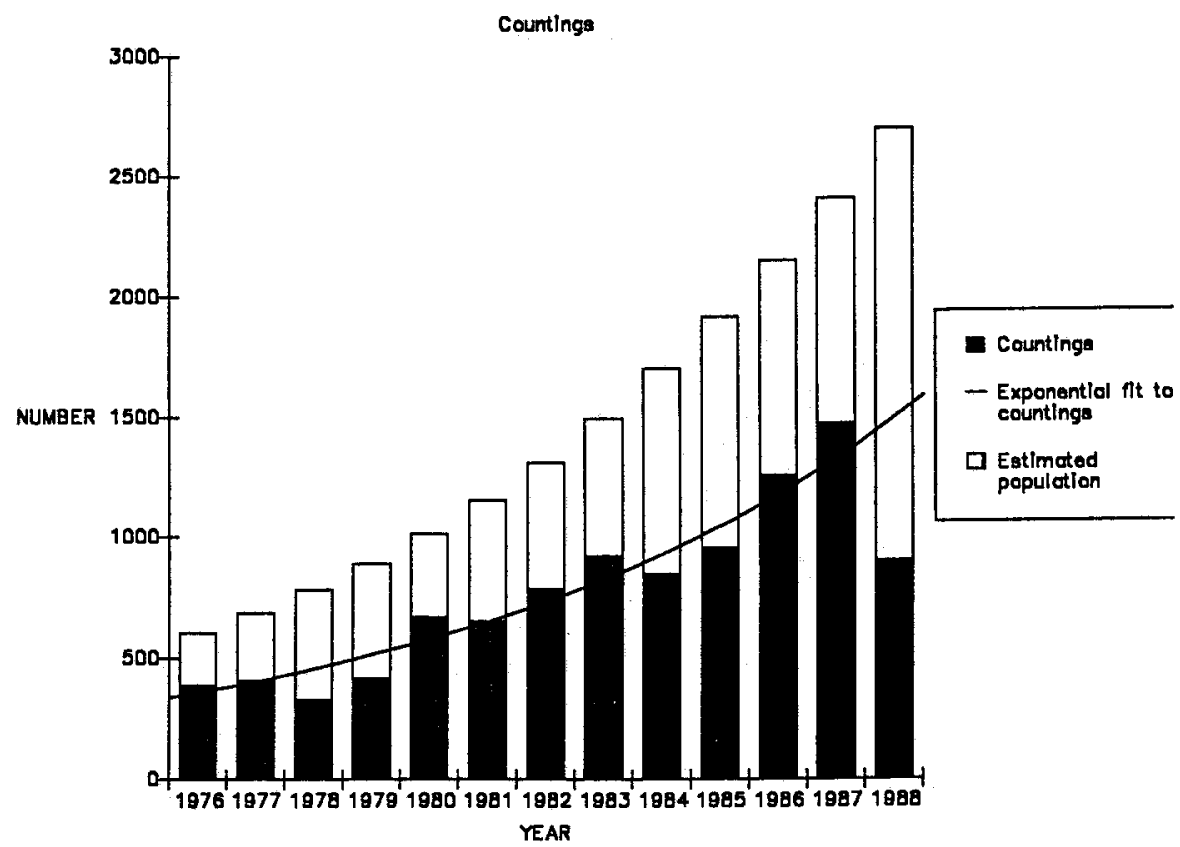

Fig. 3. A census of Phoca vitulina taken 1976-88. The average increase shows an exponential increase of approx. $14 \%$. The estimated population is outlined. The expected population in 1988 is shown, but due to the mass mortality the population is approx. $40 \%$ of the expected population 
The pattern shows a clear increase in the number of seals counted, and this should be taken as an index of a similar increase in the total population in the Danish Wadden Sea.

The seals are concentrated primarily in the central part, around Juvre Deep, between the islands of Rømø and Mandø, - the area which is also a security zone for Air Force training (Fig. 4).

In the entire area, the seals are spread over 26 haulout sites. It is extremely rare to find seals outside these localities - and, then, it is only the odd individual.

Most of the seal banks must have been used by the seals for years, as the sea-maps from the beginning of this century have several of the localities named after seals (Danish

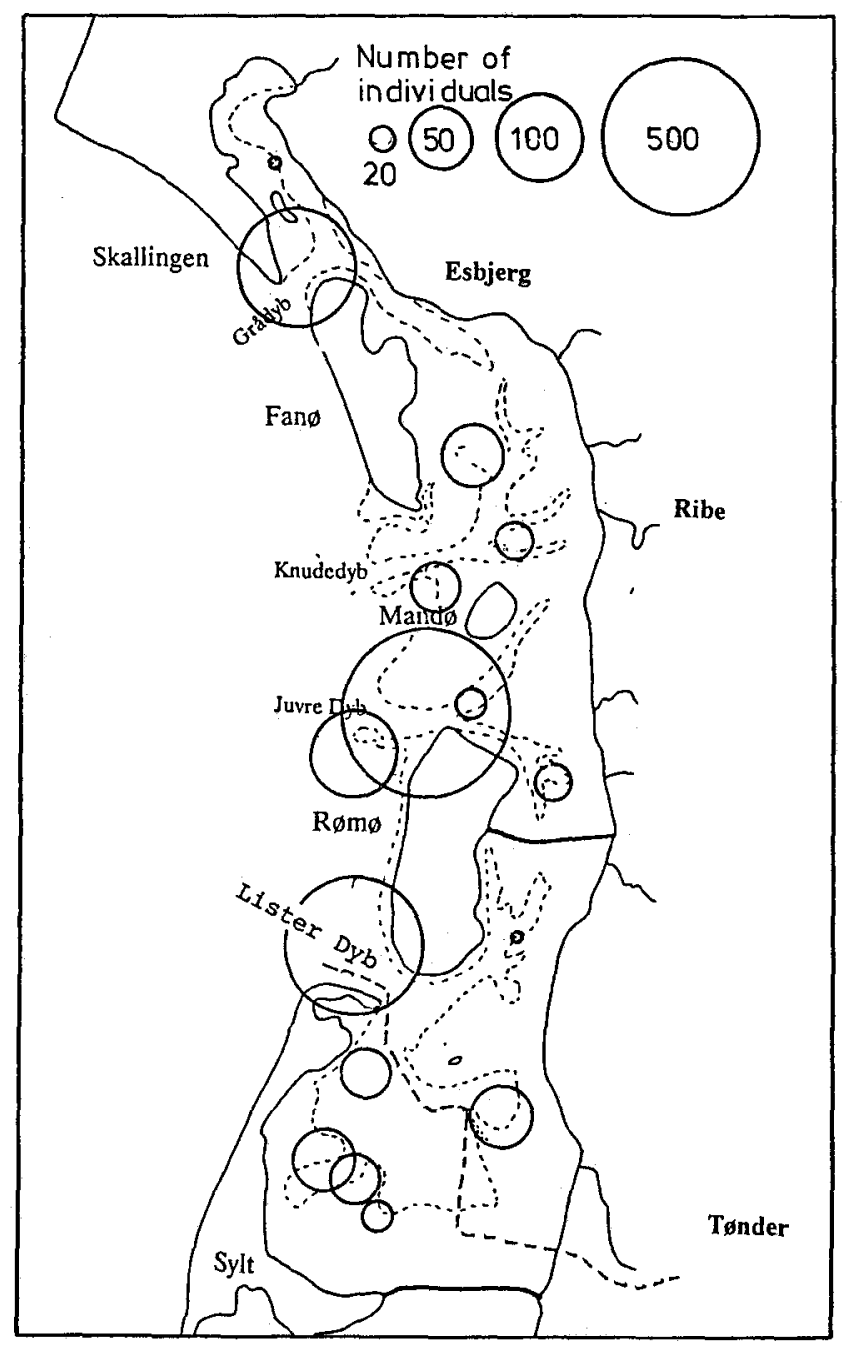

Fig. 4. The distribution according to a normal summer count (19. August 1987) shows a large amount of seals in the outer areas, mainly on the high sands. The important breeding sites are located in the inner areas 
sæl): sælhage, sælløb etc. Former sealhunters point out the same banks, as being the ones they used to hunt at the beginning of this century. The seals are found on two types of banks: the high sands, which are not flooded at normal high tides, - located in the outer parts of the Wadden Sea-, and the lower banks located in the inner parts, which are flooded at high tide and dry 4-5 hours every low tide.

Breeding takes place in the inner parts of the area, and on selected banks, where up to $30 \%$ of the animals are pups during the pupping season.

The most undisturbed banks (see Fig. 1) can clearly be recognized in the pattern of the scattering of the seals. The seals stay at a greater distance from the water on the quiet banks compared to the more disturbed banks where the seals are found in a long row

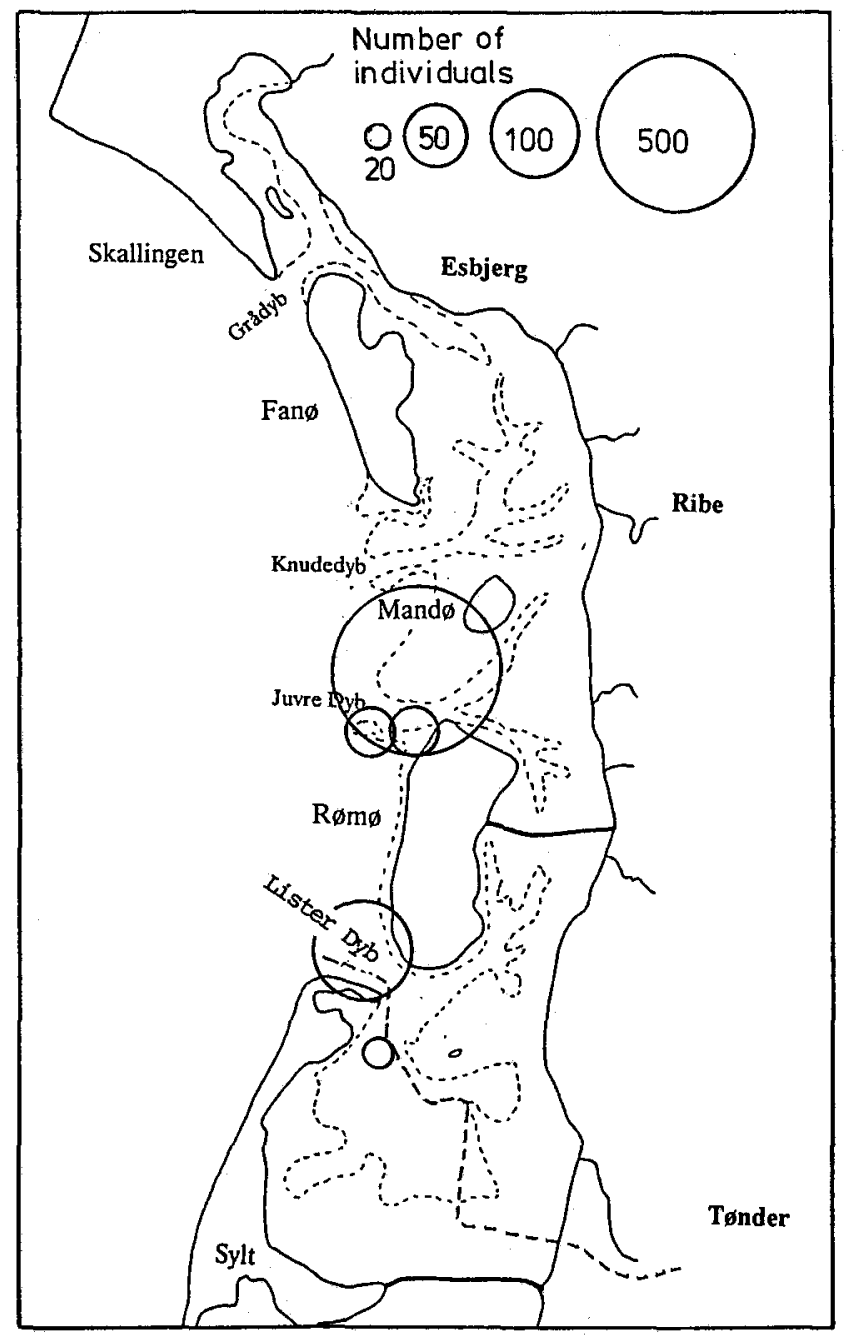

Fig. 5. Distribution of Phoca vitulina in an ice-free winter (20 January 1983). The seals' only haulout is in the outer parts of the area 
with their heads directed to the water edge, keeping close to the water by following the receding tide (see Fig. 2).

During icy winters the seals leave the area and are found on the edge of the ice with access to open water in the North Sea (fishermen comm.). In winters without ice, the seals use the high sands and the outer banks at lowtide - even in large numbers (Fig. 5).

During the breeding season, the pups are found on the special pupping banks as long as suckling takes place. After weaning, the pups frequently leave the breeding bank and are found on the high sands (Figs 6A and 6B).

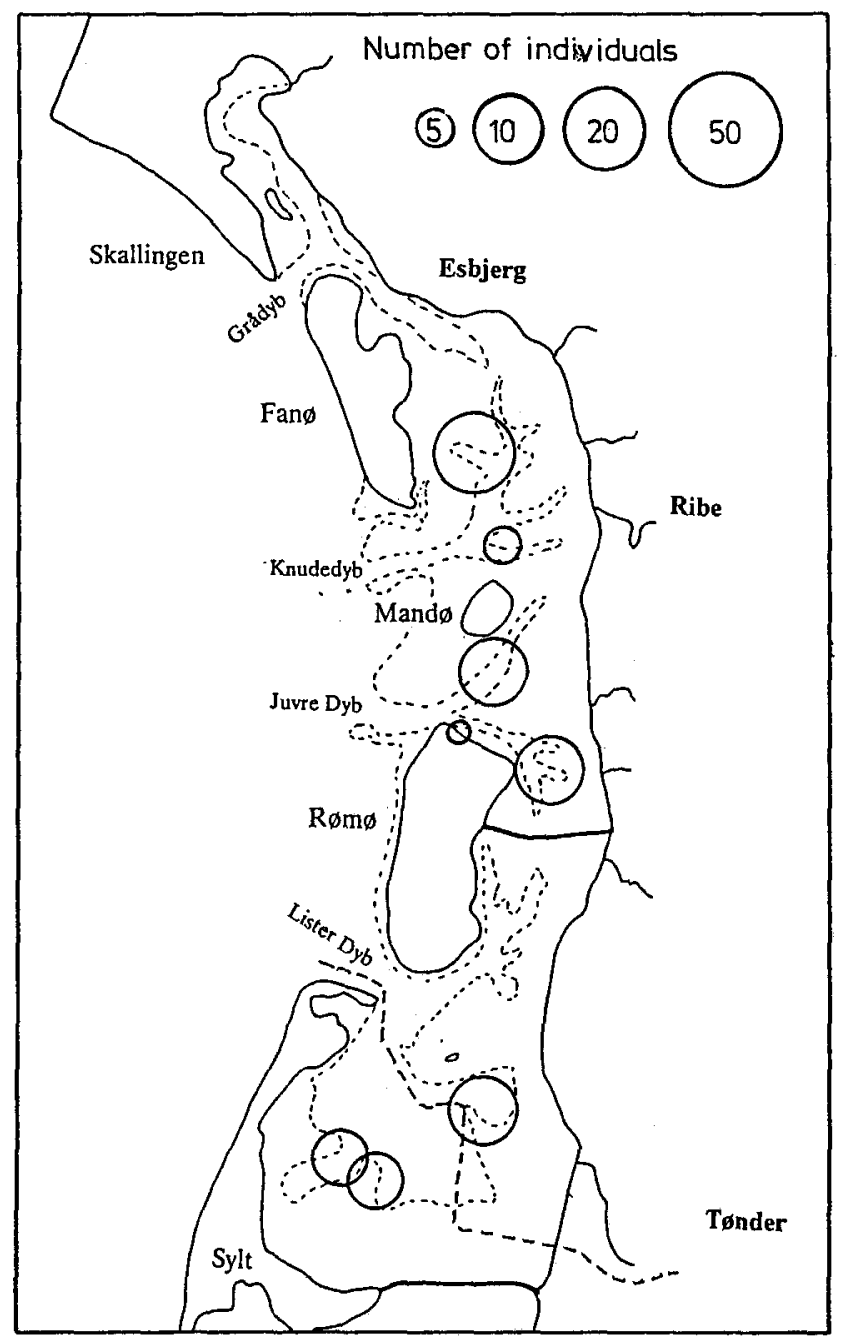

Fig. 6A. Phoca vitulina. Distribution on the breeding banks where the seal pups are born (19 July) 


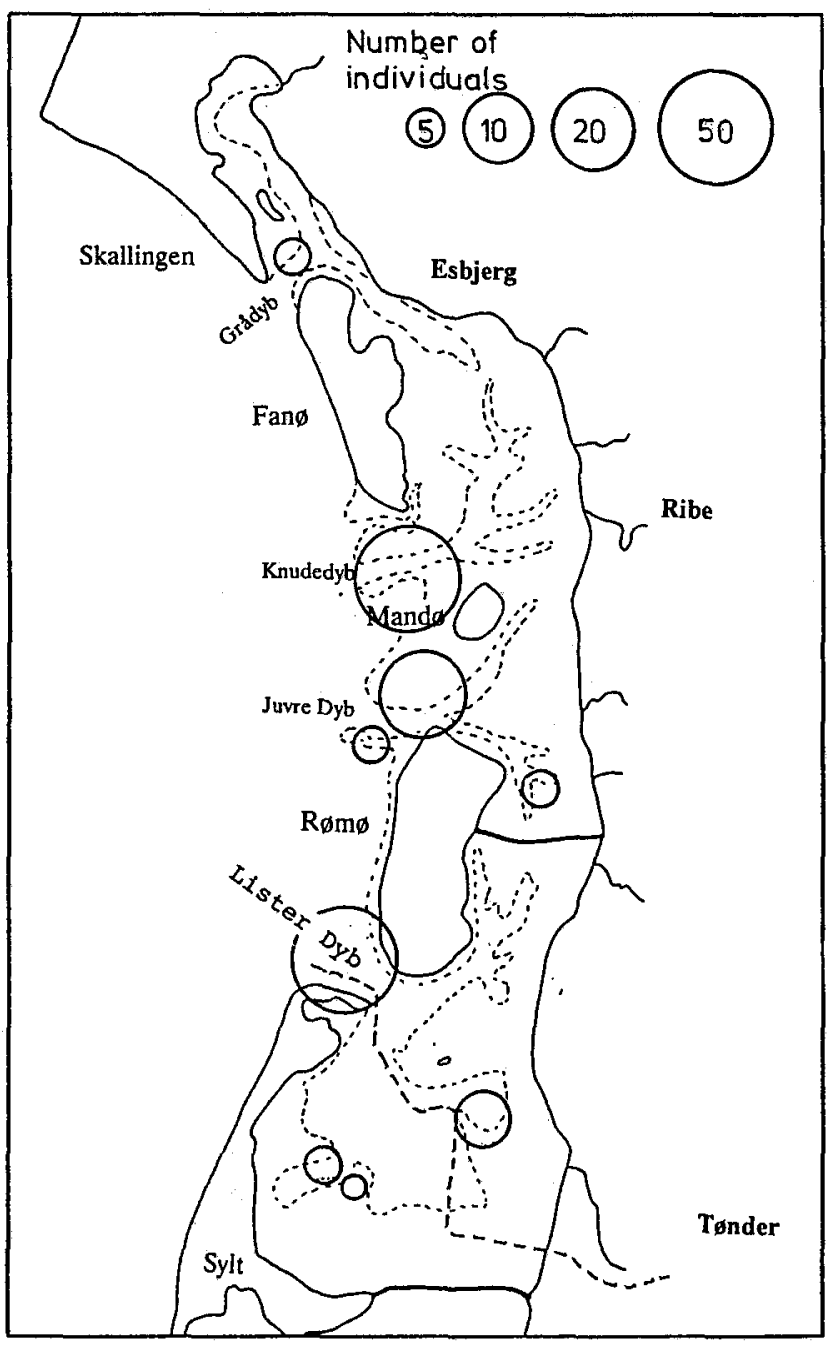

Fig. 6B. Phoca vitulina. Distribution on the high sands after the end of the suckling period (18 August)

\section{Population estimation}

The preliminary results of field studies (Nørgaard \& Tougaard, in prep.) show that $50 \%-82 \%$ of the seals related to the bank were present at low tide on a breeding bank, depending on the time of day low tide appeared. Most seals settled on the sands at low tide by day $(82 \%)$ and fewer at low tide during night $(50 \%)$.

On the average, the breeding bank is dry 5 hours at every low tide, or $42 \%$ of a 24-h period. But in the same period the seals only spend an average of 8.2 hours on land, or $34 \%$ of a $24-\mathrm{h}$ period. If it is assumed that the seals on the high sands (where it is possible to stay 24 hours a day) have the same needs for staying in the water, and the 
same preference of staying on land during day time, it is to be expected that approx. $40 \%$ of the seals related to a high sand bank stay on land during a summer day low tide.

The average distribution of the seals on high sands and low tide banks during a summer survey is $45 \%$ of the total on the high sands and $55 \%$ on low tide banks.

The counts taken on a summer day at low tide in the Danish Wadden Sea should therefore be multiplied with a factor to find the total number of the population:

$$
\text { High sands: } \frac{0.45}{0.40}+\text { low tide banks: } \frac{0.55}{0.82}=1.8
$$

These population estimations will give an expected population in 1988 of 2700 animals at the end of the summer - including this year's pups (Fig. 7).

\section{DISCUSSION}

It should be stressed that the suggested size of the population is a very preliminary estimation based on studies at one single breeding bank only. A proper estimation can be made, when studies are also carried out on high sand sites, and when a study of the migration between local banks is established.

But in the late summer of 1988, in the Danish Wadden Sea, 948 animals were found dead of the virus infection and an aerial count in the same period gave a result of 904 live animals.

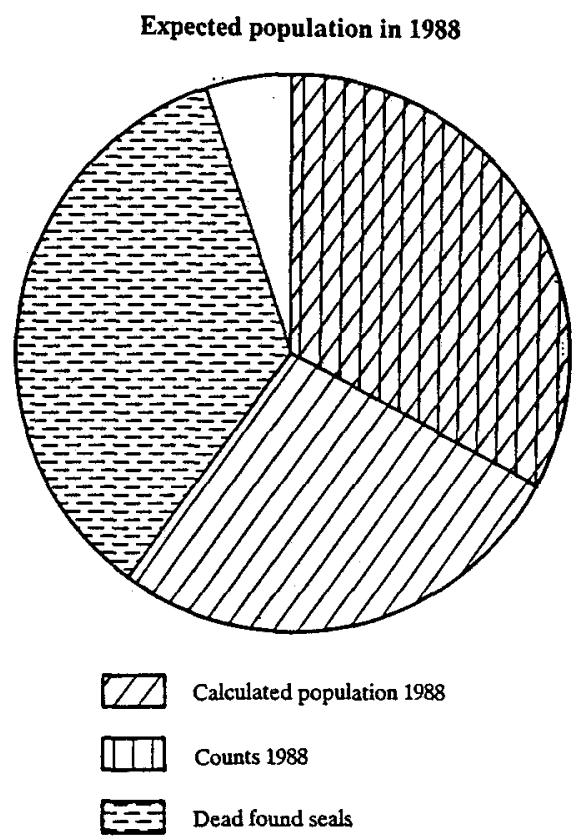

Fig. 7. The expected population size before the mass die-off in 1988 is 2700 . On the basis of the counts (904), the calculated population is estimated at 1627 . The number of seals found dead was 948 , which results in a minus of approx. $5 \%$ of the expected population 
On the basis of this aerial count, the actual population is estimated to be 1627 animals. Added to the seals found dead, this brings the total close to the estimated population of 2700 animals that was expected before the die-off.

It could be a sensible assumption that the missing 125 animals could, in part, be accounted for in the dead animals found on the northern shores of the Island of Sylt in Schleswig-Holstein that have drifted there from the southern part of the Danish Wadden Sea, and partly that the multiplication factor used is too high.

It is obvious that knowledge on the seal population in the Wadden Sea is scant, and further investigation of population dynamics, behaviour and migration has to be made in the entire International Wadden Sea to fill the gaps in this knowledge.

\section{LITERATURE CITED}

Bøgebjerg, E., 1986. Spættet sæl (Phoca vitulina) i Danmark 1976-1984. - Dansk Vildtunders. 42, $1-38$.

Drescher, H. E., 1979. Biologie, Ökologie und Schutz der Seehunde im schleswig-holsteinischen Wattenmeer, - Beitr. Wildbiol. 1979 (1), 1-74.

Reijnders, P. J. H., 1976. The harbour seal (Phoca vitulina) population in the Dutch Wadden Sea: Size and composition. - Neth. J. Sea Res. 10, 223-235.

Søndergaard, N.-O., Joensen, A. H. \& Bøgebjerg Hansen, E., 1976. Sælernes forekomst og sæljagten i Danmark. - Dansk Vildtunders. 26, 1-80. 